\title{
Scorpion Fauna and Scorpionism in Zakho Province of Northern Iraq
}

\author{
Hamid S. KACHEL
}

University of Zakho, College of Basic Education, Department of General Science, Zakho, Iraq ORCID ID: Hamid S. KACHEL: https:/ / orcid.org/0000-0002-7231-8267

\begin{abstract}
\begin{tabular}{llll}
\hline Received: 29.03 .2020 & Accepted: 20.04 .2020 & Published online: 25.04 .2020 & Issue published: 29.06 .2020 \\
\hline
\end{tabular}
Abstract: Information regarding scorpion diversity and their envenoming within Iraq in general, and the Northern Iraq in particular, is limited. The number and distribution of scorpion sting cases and some details of the scorpion fauna of Zakho province were reported for the first time in this study. Overall, 2675 scorpion sting cases were reported between 2008 and 2017 consisting of 1362 male victims (51\%) and 1313 female (49\%). The highest percentage of victims was between 15 and 49 years old and accounted for $59 \%$ of the overall incidence. The highest incidence of scorpion sting cases occurred in the summer, particularly in July when 537 cases were reported. In total, 85 scorpions belonging to two families (Scorpionidae and Buthidae) were captured in the present study. Of the collected samples, Scorpio maurus 47 (55\%) was the most abundant followed by Hottentotta saulcyi 28 (33\%), and Androctonus crassicauda 10 (12\%).
\end{abstract}

Keywords: Scorpion diversity, Scorpio maurus, Hottentotta saulcyi, Androctonus crassicauda.

\section{Kuzey Irak Zakho İli Akrep Faunası ve Skorpionizmi}

Öz: Irak genelinde ve Kuzey Irak özelinde akrep çeşitliliği ve akrep zehri ile ilgili bilgiler sınırlıdır. Akrep sokması vakalarının dağılımı ve sayısı ile ilgili bilgiler ayrıca Zakho bölgesi akrep faunası ile ilgili bazı ayrıntılar ilk kez bu çalışmada değerlendirilmiştir. Genel olarak, 2008-2017 yılları arasında kurbanların 1362'si erkek (\%51) ve 1313'ü kadın (\%49) olmak üzere 2675 akrep sokması vakası bildirilmiştir. Kurbanların en yüksek oranının 15 ile 49 yaşları arasında olduğu ve genel insidansın \% 59' unu oluşturduğu tespit edilmiştir. En yüksek akrep sokması vakaları yaz aylarında, özellikle de 537 vakanın rapor edildiği Temmuz ayında meydana gelmiştir. Toplamda, iki aileye (Scorpionidae ve Buthidae) ait 85 akrep tespit edilmiştir. Toplanan örneklerden en çok Scorpio maurus 47 (\%55)'a rastlanmışolup, bunu Hottentotta saulcyi 28 (\%33) ve Androctonus crassicauda 10 (\%12) izlenmiştir.

Anahtar kelimeler: Akrep çeşitliliği, Scorpio maurus, Hottentotta saulcyi, Androctonus crassicauda.

\section{Introduction}

The scorpion sting is considered a major public health problem in undeveloped countries in tropical and semitropical regions (Özkan, Çiftçi, \& Karaer, 2011). The venoms of 30 scorpion species among 2432 known are considered potentially hazardous to humans (Prendini, \& Wheeler, 2005; Rein, 2017). These hazardous venoms contain many peptides that are neurotoxic (Hossein, Farhad, Abbas, \& Amir, 2012). They have the ability to paralyze or kill. Other peptides with capacities to damage cells or modulate signal transduction are also present (Ernesto, \& Lourival, 2015). Each year, large numbers of scorpion stings are recorded, particularly in Mexico, Colombia, and Iran with approximately 1.2 million stings reported resulting in 3250 deaths (Kavous, Ali, Amir, Amin, \& Farzad, 2017; Bawaskar, \& Bawaskar, 2012). Scorpion envenoming has the most severe effects on children, resulting in neurological, respiratory, and cardiac abnormalities, sometimes resulting in fatalities (Altınkaynak, Ertekin, \& Alp, 2002; Boşnak et al., 2009).

Epidemiological studies on scorpion sting and diversity have been conducted in several countries in the Middle East such as Turkey (Ozkan, Adigüzel, YakiŞtiran, Cesaretli, Orman, \& Karaer, 2006), Saudi Arabia (Jarrar, \& Al-Rowaily, 2008), and Iran (Dehghani, \& Fathi, 2012). Recent unofficial reports from Iraqi Ministry of Health indicate many cases of scorpion envenoming, which vary according to region, climate, and environmental conditions. Few studies have addressed scorpion diversity and the precise numbers of cases. In this survey, we reported the diversity of scorpion species in the city of Zakho with the aim of improving our knowledge of which species cause human envenoming. We also assessed the number of cases. This work may ultimately lead to an increase in the local awareness of scorpion species present, thereby reducing the incidence of scorpion stings. It also paves the way for future studies on venom components in order to better understand their actions and to discover treatments.

The scorpion fauna of Zakho has not been searched in detail. Only Hottentotta mesopotamicus record was given by Lourenço and Qi (2007). Besides Orthochirus fomichevi and Scorpio maurus kruglovi, records were given from neighboring province Dohuk by Kovařík, Yağmur, Fet and Hussen (2019) and Pringle (1960), respectively.

\section{Material and Methods}

The study area, Zakho, is a mountain city in the Northern region of Iraq which has borders with Turkey and Syria. Zakho is located at $37^{\circ} 3^{\prime} 0^{\prime \prime} \mathrm{N}, 43^{\circ} 0^{\prime} 0^{\prime \prime} \mathrm{E}$ (Fig. 1). In the first part of this study, we present data relating to the scorpion stings obtained from the medical records of Zakho patients from various health centers collected in Shabanke central hospitals in the city of Zakho during the 10-year period from 2008 to 2017.

In the second part of the study, we examine the

*Corresponding author: Hamid.kachel@uoz.edu.krd 
diversity of scorpion species collected from four different rural and urban regions around Zakho province (Betase, Tawke, Sehela, \& Dashtamere) during the period from April to November 2018. On sunny days, scorpions can be found hidden under solid objects (wood, stone, and bricks). At night, a UV light source can be used to locate scorpions above ground (Zeina, 2016). Collected specimens were transferred to the Zoology Laboratory at the University of Zakho and individuals were maintained in small ventilated plastic boxes. Identifications were based on procedure described by Levy and Amitai (1980) and Kovař́k (2007).

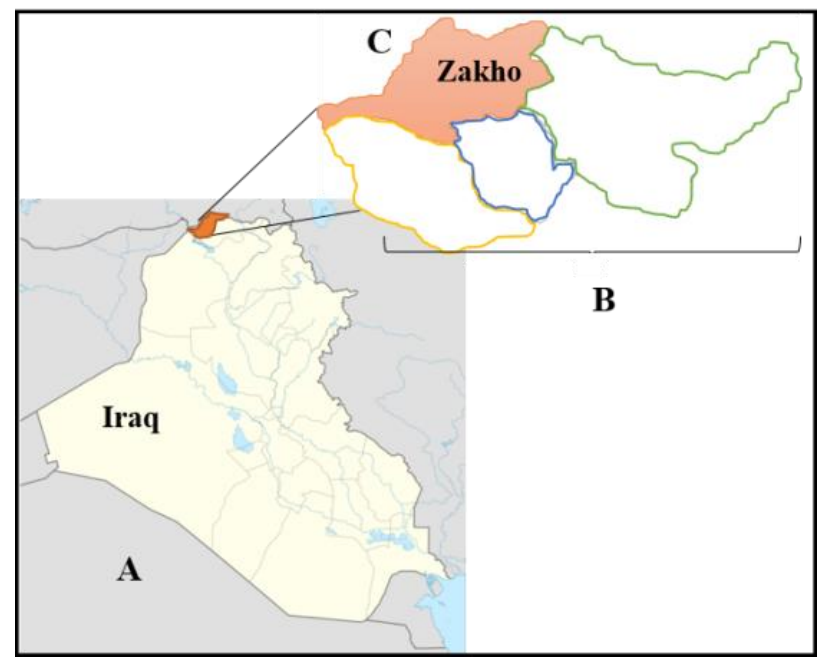

Figure 1. Maps showing the outline of (A) Iraq, (B) Duhok state, and (C) Zakho province.

\section{Results}

\subsection{Epidemiological data}

A total of 2675 scorpion sting cases were dealt with by the Shabanke central hospitals of Zakho city during the 10year period of the study from 2008-2017 (Fig. 2). This central hospital collects data of all scorpion stings cases in Zakho city. The highest numbers of cases were reported in 2017 and the lowest in 2008.

Scorpion stings were higher in summer (49\% of all cases) with the next higher seasonal incidence in autumn $(33 \%)$. The number and percentage of male and female patients stung by scorpions were 1362 (51\%) and 1313 (49\%), respectively. The monthly incidence of scorpion sting cases by genders are summarized in Table 1.

Most of the scorpion sting victims were between ages of 15 and 49 , accounting for $59 \%$ of all cases (Table 2). Those over 50 and less than 1 made up $9 \%$ and $1 \%$ of the cases, respectively.

Table 3. Classification of scorpions collected in the city of Zakho.

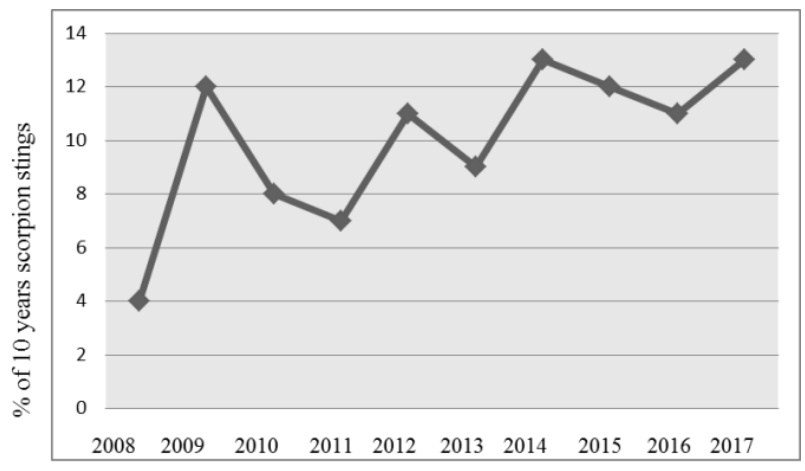

Figure 2. Incidence of scorpion stings in Zakho province between 2008 and2017.

Table 1. Monthly scorpion sting cases reported in the city of Zakho for the period of 2008-2017.

\begin{tabular}{lcccc}
\hline Month & Male & Female & Total & Percentage \% \\
\hline January & 8 & 9 & 17 & 1 \\
February & 6 & 5 & 11 & 1 \\
March & 9 & 11 & 20 & 1 \\
April & 38 & 38 & 76 & 3 \\
May & 153 & 141 & 294 & 11 \\
June & 191 & 157 & 348 & 13 \\
July & 287 & 250 & 537 & 20 \\
August & 204 & 223 & 427 & 16 \\
September & 163 & 199 & 362 & 13 \\
October & 188 & 146 & 334 & 12 \\
November & 97 & 99 & 196 & 7 \\
December & 18 & 35 & 53 & 2 \\
\hline Total & 1362 & 1313 & 2675 & 100 \\
\hline
\end{tabular}

Table 2. Age distribution for scorpion stings in the city of Zakho from 2008 to 2017.

\begin{tabular}{lcccc}
\hline Age $($ Years $)$ & Male & Female & Total & Percentage $\%$ \\
\hline Less than 1 & 19 & 10 & 29 & 1 \\
1 to 4 & 137 & 132 & 269 & 10 \\
5 to 14 & 302 & 261 & 563 & 21 \\
15 to 49 & 764 & 789 & 1553 & 59 \\
Over 50 & 103 & 119 & 222 & 9 \\
\hline Total & 1325 & 1311 & 2636 & 100 \\
\hline
\end{tabular}

\subsection{Scorpion survey in Zakho}

In the present study, eighty-five samples of scorpions were collected and maintained in the laboratory. The species collected were all members of two families (Scorpionidae and Buthidae). Scorpio maurus, Androctonus crassicauda and Hottentotta saulcyi were identified (Table 3). Hottentotta mesopotamicus has been reported previously in the study region (Lourenço, \& Qi, 2007) but it was not found among the collected samples in the present study.

\subsubsection{Scorpionidae Family}

In Iraq, the Scorpionidae family is represented by a single genus and species, Scorpio maurus. The pentagonal sternum and absence of an accessory spine on the telson are considered major morphological features of the Scorpionidae family (Zuhair, \& El-Oran, 2009).

\begin{tabular}{|c|c|c|c|c|c|c|}
\hline Phylum & Arthropod & & & Color & Number collected & $\%$ total collected \\
\hline Subphylum & Chelicerata & & & & & \\
\hline Class & Arachnida & & & & & \\
\hline Order & Scorpiones & & & & & \\
\hline Family (1) & Scorpionidae & & & & & \\
\hline \multirow{6}{*}{ Family (2) } & Genus & & Scorpio & & & \\
\hline & & Species & maurus & Yellow & 47 & 55 \\
\hline & Buthidae & & & & & \\
\hline & Genus & & Hottentotta & & & \\
\hline & & Species & saulcyi & Yellow & 28 & 33 \\
\hline & Genus & Species & $\begin{array}{l}\text { Androctonus } \\
\text { crassicauda }\end{array}$ & Black & 10 & 12 \\
\hline
\end{tabular}


Scorpio maurus (Linnaeus, 1758) (Fig. 3A)

Comments: Scorpio maurus has yellowish brown appearance with dark brown color in mesosoma and is considered non-hazardous to humans. Among the collected samples, S. maurus is accounted for 47 (55\%) scorpions and was the most frequently recorded species due to their preference to inhabit at high altitude regions ranged between $900 \mathrm{~m}$ to $1200 \mathrm{~m}$ (Salah Eddine, Youcef, \& Haroun, 2012).

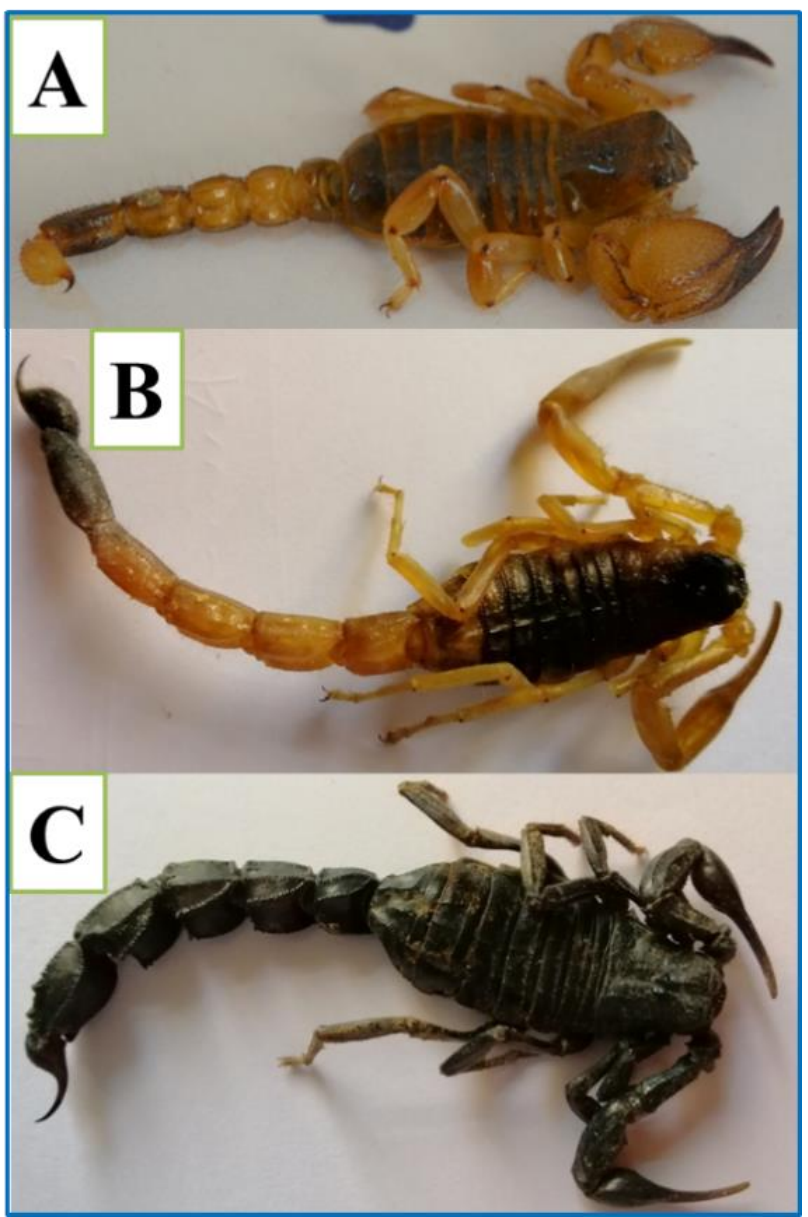

Figure 3. General overviews of scorpions in Zakho province in the Northern Iraq 2018. A. Scorpio maurus; B. Hottentotta saulcyi; C. Androctonus crassicauda. (Photos by Author).

Distribution: Taxonomically, 19 subspecies of S. maurus have been accepted. They are distributed widely in two continents: Asia (Iraq, Iran, Kuwait, Israel, Jordan, Qatar, Lebanon, Turkey, Saudi Arabia, Syria, Yemen) and Africa (Morocco, Egypt (Sinai), Senegal, Tunisia, Algeria, Congo, Egypt (Sinai), Libya, Mauritania) (Dimitris, Iasmi, \& Victor, 2008).

Distribution in Iraq: Previously, Scorpio maurus was recorded firstly from Mosul province (Penther, 1912; Khalaf, 1962). Then, it was reported in Najaf (Mishkab region) (Zeina, 2016). A subspecies, Scorpio maurus kruglovi (Birula, 1910), was recorded in Erbil city (Latifawa) in the Northern region of Iraq (Sherwan, 2015).

Examined materials: Iraq, Zakho Prov., Betase District, 800

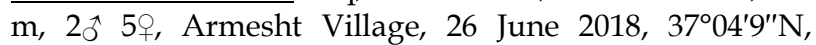

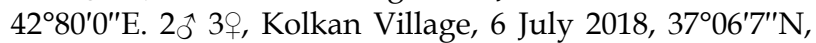

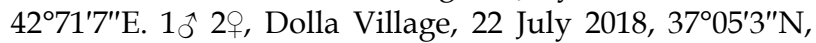

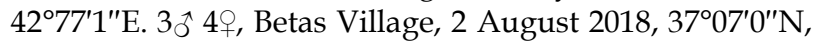

$42^{\circ} 73^{\prime} 0^{\prime \prime}$ E. Tawke District, $740 \mathrm{~m}, 1 \hat{\jmath} 2 \circ$, Wade Lawla Village, 3 July $2018,37^{\circ} 14^{\prime} 3^{\prime \prime} \mathrm{N}, 42^{\circ} 77^{\prime} 4^{\prime \prime} E$. $20^{\hat{2}} 2$, , Terk

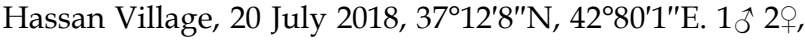
Omer Axa Village, 2 September 2018, 37015'1"N, 42 $78^{\prime} 6^{\prime \prime} \mathrm{E}$. Dashtamere District, 790 m, 20 5ㅇ, Kane Rahal Village, 19

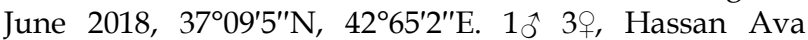
Village, 8 August 2018, 37 $08^{\prime} 5^{\prime \prime} \mathrm{N}, 42^{\circ} 66^{\prime} 0^{\prime \prime} \mathrm{E}$. Sehela District, 690 m, 1ðิ 3ㅇ, Derabon Village, 4 July 2018, $37^{\circ} 08^{\prime} 5^{\prime \prime} \mathrm{N}, 42^{\circ} 42^{\prime} 6^{\prime \prime}$ E. 1 우, Shenawa Village, 18 August 2018, $37^{\circ} 11^{\prime} 8^{\prime \prime} \mathrm{N}, 42^{\circ} 51^{\prime} 5^{\prime \prime} \mathrm{E}$.

\subsubsection{Buthidae Family}

Buthidae is the largest of all scorpion families and includes most of the medically important scorpions. Scorpions from this family can cause severe envenomation which is sometimes lethal to the elderly and children (Sahin, Ozturk, \& Demiraran, 2014). The triangular sternum together with the presence of accessory spines on telson is the main prominent characteristic of this family (Zuhair, \& El-Oran, 2009).

\section{Androctonus crassicauda (Olivier, 1807) (Fig. 3C)}

Comments: Androctonus crassicauda is black in color and has a wide, thickly segmented tail. In this survey, only 10 individuals of this species were captured. A. crassicauda generally prefers low altitude localities and has been collected previously in the middle and southern part of Iraq (Zeina, \& Sabah, 2016). This species inhabits under cemetery stones, inside sand and soil in plain (Mulood et al., 2017). However, in this study, it was found in a higher place at attitude range from $600 \mathrm{~m}$ to $900 \mathrm{~m}$, Zakho city, northern part of Iraq. It is one of the widely distributed species in Iraq.

Distribution: A. crassicauda is distributed in countries such as Azerbaijan, United Arab Emirates, Libya, Turkey, Bahrain, Armenia, Egypt, Iran, Israel, Jordan, Kuwait, Oman, Saudi Arabia, Syria, and Yemen (Fet \& Lowe, 2000; Dimitris et al., 2008).

Distribution in Iraq: A. crassicauda is widely spread in Iraq. A study by Pringle (1960) reported it for the first time in Iraqi cities of Baquba, Aqra, Basra, Mosul, and Hilla. Then, it was recorded from Babel, Najaf (Haider, \& Mohammad, 2010), Baghdad, Diyala, Salah al-Din, Qadissiya, Wasit, and Thi-Qar provinces (Zeina, \& Sabah, 2016).

Examined materials: Iraq, Zakho Prov., Sehela District, 690

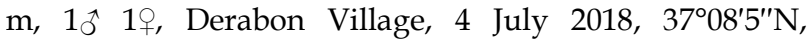

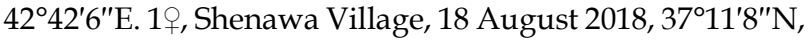
$42^{\circ} 51^{\prime} 5^{\prime \prime}$. Tawke District, $740 \mathrm{~m}, 1$, , Wade Lawla Village, 3 July $2018,37^{\circ} 14^{\prime} 3^{\prime \prime} \mathrm{N}, 42^{\circ} 77^{\prime} 4^{\prime \prime}$ E. $1 \hat{\jmath}^{\wedge}$, Terk Hassan Village,

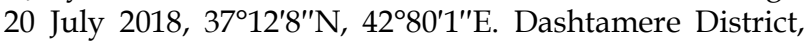

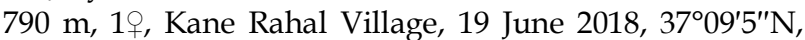
$42^{\circ} 65^{\prime} 2^{\prime \prime}$ E. $1 \delta^{\hat{0}} 1$ 우, Hassan Ava Village, 8 August 2018, $37^{\circ} 08^{\prime} 5^{\prime \prime} \mathrm{N}, 42^{\circ} 66^{\prime} 0^{\prime \prime} \mathrm{E}$. Betase District, $800 \mathrm{~m}, 1$, , Armesht Village, 26 June $2018,37^{\circ} 04^{\prime} 9^{\prime \prime} \mathrm{N}, 42^{\circ} 80^{\prime} 0^{\prime \prime} \mathrm{E}$.

Hottentotta salucyi (Simon, 1880) (Fig. 3B)

Comments: Hottentotta saulcyi are yellow in color with a black tail end. $28 \mathrm{H}$. saulcyi were captured accounting for $33 \%$ of all scorpions captured. H. saulcyi is distributed widely in northern region of Iraq and inhabits in calcareous soil. The specimens were collected in a mountain region at elevation between $650 \mathrm{~m}$ to $1000 \mathrm{~m}$. Previous studies in Turkey and Iran recorded H. saulcyi 
species at elevation between $1100 \mathrm{~m}$ to $2000 \mathrm{~m}$, respectively (Yağmur, Koç, \& Yalçın, 2008b; Moradi, Yağmur, Gharakhloo, \& Ahmadi, 2015).

Distribution: $H$. saulcyi has only been known in Asian countries like Iraq, Turkey, Iran, Afghanistan, and Syria (Dimitris et al., 2008). This species in Turkey was recorded from the southeastern part of the country (Yağmur et al., 2008 b), while according to Kovařík (2007) H. saulcyi records for Syria must be considered dubious.

Distribution in Iraq: $H$. saulcyi is known in Iraq from the city of Mosul (Lourenço, \& Qi, 2007) and Kirkuk (Brwa, Kasim, Khalil, \& Kamal, 2018).

Examined materials: Iraq, Zakho Prov., Betase District, 800

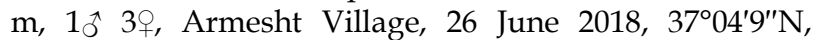

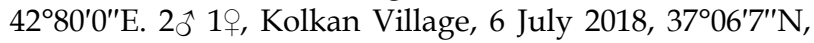

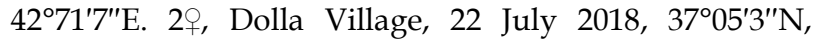

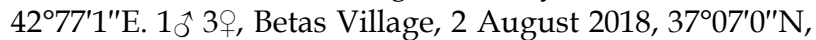
$42^{\circ} 73^{\prime} 0^{\prime \prime} \mathrm{E}$. Dashtamere District, $790 \mathrm{~m}, 1{ }^{\wedge} 2$ 우, Kane Rahal

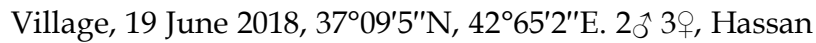
Ava Village, 8 August $2018,37^{\circ} 08^{\prime} 5^{\prime \prime} \mathrm{N}, 42^{\circ} 66^{\prime} 0^{\prime \prime} \mathrm{E}$. Tawke District, $740 \mathrm{~m}, 1$ 우, Wade Lawla Village, 3 July 2018,

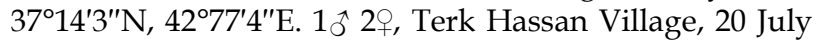

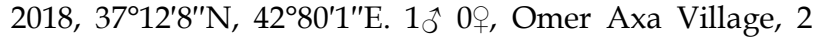
September 2018, 37 $15^{\prime} 1^{\prime \prime} \mathrm{N}, 42^{\circ} 78^{\prime} 6^{\prime \prime}$ E. Sehela District, 690 $\mathrm{m}, 0 \hat{\mathrm{s}}$ 1우, Derabon Village, 4 July $2018,37^{\circ} 08^{\prime} 5^{\prime \prime} \mathrm{N}$, $42^{\circ} 42^{\prime} 6^{\prime \prime}$ E. 0ô 1우, Shenawa Village, 18 August 2018, $37^{\circ} 11^{\prime} 8^{\prime \prime} \mathrm{N}, 42^{\circ} 51^{\prime} 5^{\prime \prime} \mathrm{E}$.

\section{Discussion}

Understanding local scorpion diversity is the starting point in identifying the main species responsible for envenomation. Over the previous decade, Scorpionism has become a common public health threat in Central and South America, Africa, the Middle East, and South and Central Asia (Masoud \& Hasan, 2017) and particularly in the countries neighboring Northern Iraq, such as Turkey (Ozkan et al., 2006) and Iran (Dehghani, \& Fathi, 2012). Northern Iraq is a mountainous region. It is likely that scorpion diversity in this region is greater than currently known as little work has been undertaken to date. Life in this predominantly rural area of Northern Iraq is strongly dependent on agriculture and this results in increased risk of contact with scorpions, thereby increasing the incidence of stings among agricultural workers and children particularly when removing trees, wood, and stones (Zuhair, Renad, Nour, \& Rihan, 2017).

This is the first report on scorpion envenomation and diversity in Zakho province spanning the 10-year period from 2008 to 2017. The presented data show that men $(51 \%)$ and women $(49 \%)$ are equally likely to suffer stings. This finding is in agreement with the finding from work undertaken in Saudi Arabia (Jarrar \& Al-Rowaily, 2008). On the other hand, our result is in contrast with previous studies conducted in Iran (Khodabakhsh, Babak, Eman, Muhsen, \& Seyed, 2013; Rahmani etal., 2015) which showed that number of female patients presenting with scorpion stings was higher than for males.

Although the incidence of Scorpionism in Zakho was high, mortality was zero in the period investigated. This may be due to the access to medical care combined with the availability of effective anti-venoms. This finding was in agreement with a previous investigation carried out in
Iran by Esmaeil, Mulood, Shahla, Abedin, Nahid, Eslam, and Alireza (2018), while in other studies around the world different death rates have been reported after scorpion stings. This is presumably because of the species of scorpion responsible and the availability of medical care and anti-venom (El Hidan, Touloun, \& Boumezzough, 2015; Araújo, Tavares, Marques, Vieira, \& Leite, 2017).

The scorpion activity is highly temperaturedependent. Therefore, the highest rate of scorpion stings are reported in summer (Dehghani \& Fathi, 2012; Kassiri et al., 2013). The findings of the present investigation are in agreement with the previous studies conducted in Iran (Esmaeil et al., 2018) which reports that most frequent incidences of scorpion stings are recorded during the hot period of the year (May to September), with the highest proportion of stings, 20\% occurring in July (Esmaeil et al., 2018). The high sting incidences recorded in 2009 and after 2014 are likely attributed to the large increase in the numbers of displaced people to Zakho providence and their poor living standards.

Our study showed that more than half of all the scorpion stings (59\%) occurred between the age range 15 49 years. In the related studies, this age range has been identified as high risk that might be due to outdoor working and activity outside the home. Kassiri et al., (2014) from Iran showed that young people aged between 15-24 years have the highest scorpion sting incidence. Similarly, the age group 20-29 years has more scorpion sting according to Barros, Pasquino, Peixoto, Targino, de Sousa, and Leite (2014). A study by Talebian and Doroodgar (2006) showed that the highest numbers of scorpion stings occurred among the children aged less than 10 years.

The data from the second section of the present survey showed limited scorpion diversity among species collected in Zakho region, with two families and at least three species identified. To date, several scorpion species belonging to many families have been recorded in Iraq (Scorpions in Iraq, 2007), a few of them are medically important. In the current survey, Androctonus crassicauda (Man-Killer fat-tailed scorpion), one of the medically important venomous species, was found and this species has also been reported from neighboring countries such as Saudi Arabia, Jordan, Iran, Syria, and Turkey (Yağmur, Yalçın, \& Çalışır, 2008a; Karataş \& Çolak, 2005). According to the previous surveys in Iran, A. crassicauda was responsible for $28 \%$ of the scorpion stings (Vazirianzadeh, \& Salahshoor, 2015). Their stings are painful to patients and sometime cause death among infants (Khodadadi, Pipelzadeh, Vazirianzadeh, Pipelzadeh, \& Sharifat, 2012). The other large size Buthidae species collected in the Zakho area was Hottentotta saulcyi (Simon, 1880). This species has been found in Mosel, a city close to Zakho province in Iraq, and nearby countries such as Turkey and Iran (Yağmur et al., 2008b; Jalil et al., 2018). Hottentotta mesopotamicus another Hottentotta species is smaller than $H$. saulcyi has previously been reported from Zakho province (Lourenço \& Qi, 2007). Although samples of $H$. mesopotamicus. Hottentotta species, H. scaber (Ehrenberg, 1828), and H. schach (Birula, 1905) have also been reported from Iraq but not in the present study.

Several bioactive peptides have been identified and characterized previously from scorpion crude venom by 
using high performance liquid chromatography. These peptides are structurally categorized as non-disulfide and disulfide bridge-containing peptides (Almaaytah \& Albalas, 2014; Santibanez-Lopez \& Possani, 2015). The majority of the non-disulfide peptides act as antimicrobials by disrupting cell membrane structures (Harrison, AbdelRahman, Miller, \& Strong, 2014). On the other hand, numerous disulfide bridge-containing peptides selectively interact with particular ion channels $\left(\mathrm{Na}^{+}, \mathrm{K}^{+}, \mathrm{Cl}^{-}\right.$and $\left.\mathrm{Ca}^{2+}\right)$ in the nervous system (Zhijian, Feng, Yingliang, Xin, \& Wenxin, 2006; Housley, Liddell, \& Jennings, 2017).

The most abundant scorpion (55\% of all collected) is S. maurus, belonging to Scorpionidae family; though, it is not considered medically important. Worldwide this family includes 265 scorpion species belonging to 17 genera and they are found on several continents including Oceania (Australia), Africa, Asia, and America.

\section{Conclusion}

It is important to provide information for Zakho province residents with regard to scorpion subtype diversity and prevention strategies toward Scorpionism. A. crassicauda is a dangerous, medically important scorpion and is present in the study area, along with two other scorpions, $H$. saulcyi and S. maurus. Further studies are required on the scorpion fauna of the Northern Iraq including various aspects such as ecology, distribution, morphology, abundance, biogeographic and association between scorpion species, and their clinical signs and symptoms. This region is not well studied in terms of scorpion species diversity. Therefore, the data presented in this study serve as novel knowledge regarding scorpion fauna of the Northern Iraq and the seasonal, age, and gender distribution of envenoming.

\section{References}

Almaaytah, A., \& Albalas, Q. (2014). Scorpion venom peptides with no disulfide bridges: A review. Peptides, 51, 35-45. doi: 10.1016/j.peptides.2013.10.021.

Altınkaynak, S., Ertekin, V., \& Alp, H. (2002). Scorpion envenomation in children. Turkish Archives of Pediatrics, 37, 48-54.

Araújo, K., Tavares, A., Marques, M., Vieira, A., \& Leite, R. (2017). Epidemiological study of scorpion stings in the Rio Grande do Norte State, Northeastern Brazil. Revista do Instituto de Medicina Tropical de São Paulo, 7, 59, e58. doi: 10.1590/S1678-9946201759058.

Barros, R., Pasquino, J., Peixoto, L., Targino, I., de Sousa, J., \& Leite, R. (2014). Clinical and epidemiological aspects of scorpion stings in the northeast region of Brazil. Ciencia and saude coletiva, 19, 1275-82. https:/ / doi.org/10.1590/1413-81232014194.01602013

Bawaskar, H., \& Bawaskar, P. (2012). Scorpion sting: update. The Journal of the Association of Physicians of India, 60, 46-55

Bossnak, M., Ece, A., Yolbaș, I., Boşnak, V., Kaplan, M., \& Gürkan, F. (2009). Scorpion sting envenomation in children in southeast Turkey. Wilderness \& Environmental Medicine, 20, 118-124.

Brwa, N., Kasim, S., Khalil, A., \& Kamal, A. (2018). Preparation of F(ab')2 antivenom in Iraq against scorpion (Hottentotta saulcyi) venom. Biologicals, https://doi.org/10.1016/j.biologicals.2018.08.005

Dehghani, R., \& Fathi, B. (2012). Scorpion sting in Iran: A review. Toxicon, 60, 919-33. DOI: 10.1016/j.toxicon.2012.06.002

Dimitris, K., Iasmi, S., \& Victor, F. (Eds. 2008). Scorpions of the Eastern Mediterranean. Advances in Arachnology and Developmental Biology, 12, 209-246.

Ernesto, O., \& Lourival, D. (2015). The unfulfilled promises of scorpion insecto toxins. Journal of Venomous Animals and Toxins including Tropical Diseases, 21, 16-22. https://doi.org/10.1186/s40409-015-0019-6

El Hidan, M., Touloun, O., \& Boumezzough, A. (2015). An epidemiological study on scorpion envenomation in the Zagora oases (Morocco). Journal of Coastal Life Medicine, 3, 704-707. DOI: 10.12980/jclm.3.2015j5-86
Esmaeil, G. Mulood, M. Shahla, J. Abedin, S. Nahid, J. Eslam, M., \& Alireza, O. (2018). Spatial Distribution of Scorpionism in Ardabil Province, North West of Iran. International Journal of Pediatrics, 6, 8241-51. Doi: 10.22038/IJP.2018.30029.2644

Fet, V., \& Lowe, G. (2000). Family Buthidae. pp. 54-286. In: V., Fet, W.D., Sissom, G. Lowe, and M.E. Braunwalder (Eds), Catalog of the Scorpions of the World (1758-1998). New York, USA, The New York Entomological Society, $690 \mathrm{pp}$.

Haider, M., \& Mohammad, H. (2010). Diagnostic and epidemiologic Study of fat tailed scorpion (Androctonus crassicauda) in Mid-Euphrates region/Iraq. College of veterinary medicine / Babil Univ./Babil/Iraq

Harrison, P., Abdel-Rahman, M., Miller, K., \& Strong, P. (2014). Antimicrobial peptides from scorpion venoms. Toxicon, 88, 115-137. doi: 10.1016/j.toxicon.2014.06.006

Hossein, V., Farhad, A., Abbas, Z., \& Amir, J. (2012). Two biological active fractions isolated from Buthotus schach (BS) scorpion venom examined on striated muscle preparation in-vitro. Iranian Journal of Pharmaceutical Research, 11, 905-911.

Housley, D., Housley, G., Liddell, M., \& Jennings, E. (2017). Scorpion toxin peptide action at the ion channel subunit level. Neuropharmacology, 127 46-78. https://doi.org/10.1016/j.neuropharm.2016.10.004

Jalil, N., Abedin, S., Javad, R., Ehsan, M., Amir, K., Ali, A., \& Amir, T. (2018). Scorpion composition and scorpionism in a high-risk area, the southwest of Iran. Electronic Physician, 10, 7138-7145. doi: 10.19082/7138

Jarrar, B., \& Al-Rowaily, M. (2008). Epidemiological aspects of scorpion stings in Al-Jouf Province, Saudi Arabia. Annals of Saudi Medicine, 28,183-187. doi: 10.5144/0256-4947.2008.183

Kassiri, H., Shemshad, K., Kassiri, A., Shemshad, M., Valipor, A., \& Teimori, A. (2013). Epidemiological and climatological factors influencing on scorpion envenoming in Baghmalek County, Iran. Academic Journal of Entomology, 6, 47-54. DOI: 10.5829/idosi.aje.2013.6.2.751

Kassiri, H. Kassiri, A. Sharififard, M. Shojaee, S. Lotfi, M., \& Kasiri, E. (2014). Scorpion envenomation study in Behbahan County, Southwest Iran. Journal of Coastal Life Medicine, 2,416-20.

Karataş, A., \& Çolak, M. (2005). Scorpions of Gaziantep Province, Turkey (Arachnida: Scorpiones). Euscorpius, 30, 1-7. https://dx.doi.org/10.18590/euscorpius.2005.vol2005.iss30.1

Kavous, Sh., Ali, T., Amir, G., Amin, Sh., \& Farzad, R. (2017) Epidemiological and clinical status of patients with scorpion sting: emergency department of Sina hospital in Tabriz-Iran. Journal of Emergency Practice and Trauma, 3,18-21. https://dx.doi.org/10.15171/jept.2017.08

Khalaf, L. (1962). Asmall Collection of Scorpions from Iraq. Bulletin of the Iraq Natural History Museum 2(4), 1-3.

Khodadadi, A., Pipelzadeh, M., Vazirianzadeh, B., Pipelzadeh, M., \& Sharifat, M. (2012). An in vitro comparative study upon the toxic properties of the venoms from Hemiscorpius lepturus, Androctonus crassicauda and Mesobuthus eupeus scorpions. Toxicon, 60, 385-90.

Khodabakhsh, K., Babak, V., Eman, M., Muhsen, H., \& Seyed, A. (2013). A Five Year Epidemiologic Study on Scorpion Stings in Ramhormoz, South-West of Iran. Pakistan Journal of Zoology, 45, 469-474.

Kovařík, F. (2007). A revision of the genus Hottentotta Birula, 1908, with descriptions of four new species (Scorpiones, Buthidae), Euscorpius, 58, 1-107. https://dx.doi.org/10.18590/euscorpius.2007.vol2007.iss58.1

Kovař́ik, F., Yağmur, E.A., Fet, V., \& Hussen, F.S. (2019). A review of Orthochirus from Turkey, Iraq, and Iran (Khoozestan, Ilam, and Lorestan Provinces), with descriptions of three new species (Scorpiones: Buthidae), Euscorpius, 278, 1-31 https://dx.doi.org/10.18590/euscorpius.2019.vol2019.iss278.1

Levy, G., \& Amitai, P. (1980). Scorpiones, In: Fauna Palaestina, Arachnida I. Jerusalem, Israel, Israel Academy of Sciences and Humanities, $130 \mathrm{pp}$.

Lourenço, W., \& Qi, J. (2007). Description of a new species of the genus Hottentotta Birula, 1908 (Scorpiones: Buthidae) from Iraq. Zoology in the Middle East, $41, \quad 99-104$. https://doi.org/10.1080/09397140.2007.10638232

Masoud, A., \& Hasan, A. (2017). Epidemiological Study of Scorpion Sting in Lordegan City during the Years 2014- 2017. Journal of Community Health Research, 7, 57-61.

Moradi, M., Yağmur, E., Gharakhloo, P., \& Ahmadi, F. (2015). Scorpion Fauna of Zanjan Province, Iran (Arachnida: Scorpiones). Journal of Applied Biological Sciences, 9(1), 11-14.

Mulood, M., Javad, R., Ahmad, A., Mohammad, A., Shahrokh, N., Farrokh, D., Mehdi, B., \& Masoomeh, B. (2017). Spatial Distribution of Medically Important Scorpions in North West of Iran. Journal of Arthropod-Borne Diseases, 11(3), 371-382. 
Ozkan, O., Adigüzel, S., Yakiştiran, S., Cesaretli, Y. Orman, M., \& Karaer, K. (2006). Androctonus crassicauda (Olivier 1807) scorpionism in the Şanlıurfa provinces of Turkey. Türki Acta Parasitologica Turcica, 30, 239245.

Özkan, Ö., Çiftçi, G., \& Karaer, Z. (2011). Electrophoretical Comparison of Proteins of Mesobuthus eupeus and Mesobuthus gibbosus Scorpion Venoms. Kafkas Universitesi Veteriner Fakultesi Dergisi, 17, 153-158. DOI:10.9775/kvfd.2011.4190

Penther, A. (1912). Expedittion Mesopotamien Scorpiones. Annalen des K. K. Naturhistorischen Hofmuseums, 26, 109-116.

Prendini, L., \& Wheeler, W. (2005). Scorpion higher phylogeny and classification, taxonomic anarchy, and standards for peer review in online publishing. Cladistics, 21, 446-94.

Pringle, G. (1960). Notes on The Scorpiones of Iraq. Bulletin of Endemic Diseases, 3(3-4), 73-87.

Rahmani, A., Forouzandeh, H., Kalantar, M., Asad-Masjedi, N., Alavian, Z., \& Kavarizadeh, K. (2015). Epidemiological and Clinical Characteristics of Scorpion Stings in Ahwaz, Southwest Iran (2006-2010). International Journal of Medical Toxicology and Forensic Medicine, 5, 201-206.

Rein, J. (2017). The Scorpion Files. Trondheim: Norwegian University of Science and Technology. Retrieved from https://www.ntnu.no/ub/scorpion-files/.

Sahin, A., Sahin, M., Ozturk, N., \& Demiraran, Y. (2014). Sever cardiovascular dysfunction and pulmonary edema in children with scorpion envenomation. Journal of medicine and medical research, 2, 84-88.

Salah Eddine, S., Youcef, A., \& Haroun, Ch. (2012). First data on scorpion diversity and ecological distribution in the National Park of Belezma, Northeast Algeria. Serket, 13(1/2), 27-37.

Santibanez-Lopez, C., \& Possani, L. (2015). Overview of the Knottin scorpion toxin-like peptides in scorpion venoms: Insights on their classification and evolution. Toxicon, 107, 317-326. https://doi.org/10.1016/j.toxicon.2015.06.029

Scorpions in Iraq (update 1.11.2007). Retrieved from https://www.ntnu.no/ub/scorpion-files/scorpions_iraq.php.

Sherwan, T. (2015). Morphology and Histology of Venom Gland of Scorpio maurus kruglovi (Birula, 1910) (Scorpionidae: Scorpiones). Zanco Journal of Pure and Applied Sciences, 27, 59-62.

Talebian, A., \& Doroodgar, A. (2006). Epidemiologic study of scorpion sting in patients referring to Kashan medical centers during 1991-2002. Iranian Journal of Clinical Infectious Diseases, 1, 191-194.

Vazirianzadeh, B., \& Salahshoor, A. (2015). Scorpion Sting in Izeh, Iran: An Epidemiological Study during 2009-2011. Journal of Basic \& Applied Sciences, 11, 403-409.

Yağmur, E.A., Yalçın, M., \& Çalışır, G. (2008a). Distribution of Androctonus crassicauda (Olivier, 1807) and Buthacus macrocentrus (Ehrenberg, 1828) (Scorpiones: Buthidae) in Turkey. Serket, 11,13-18.

Yağmur, E.A., Koç, H., \& Yalçın, M. (2008b). Distribution of Hottentotta saulcyi (Simon, 1880) (Scorpiones: Buthidae) in Turkey. Euscorpius, 76, 1-6. https://dx.doi.org/10.18590/euscorpius.2008.vol2008.iss76.1

Zeina, N. (2016). List of Scorpions Recorded for the First Time in Iraq. Ibn Al-Haitham Journal for Pure and Applied Sciences, 29, 49-57.

Zeina, N., \& Sabah, F. (2016). Taxonomic study of Androctonus crassicauda (oliver, 1807) (scorpiones: buthidae) in Iraq. Bulletin of the Iraq Natural History Museum,14(1),13-25.

Zhijian, C., Feng, L., Yingliang, W., Xin, M., \& Wenxin, L. (2006). Genetic mechanisms of scorpion venom peptide diversification. Toxicon, 47, 348-355. https://doi.org/10.1016/j.toxicon.2005.11.013

Zuhair, S.A., \& El-Oran, R. (2009). Systematics and distribution of scorpion (Arachnida, Scorpionida) in Jordan. Bollettino di zoologia, 61, 185-190. https://doi.org/10.1080/11250009409355881

Zuhair, S., Renad, A., Nour, A., \& Rihan, B. (2017). Scorpion Stings in Jordan: An Update. wilderness \& environmental medicine, 28, 207-212. https://doi.org/10.1016/j.wem.2017.05.003 